\title{
The Future Federal Role between Government and Higher Education
}

\begin{abstract}
In the 1980s, the federal government's role in higher education should be focused on controlling inflation, ensuring equality of services, reducing regulation and paperwork burdens, and improving quality. Its primary budget strategy will be reduction of federal funding, while it will continue to provide assistance to lower-income families as well as supplemental aid to students. Major federal programs will include improvement in the quality of higher education, ensuring continuous access by all Americans to higher education, support for the "historically black colleges," and expansion of language and area studies. Although the cabinet status of the Department of Education will probably be removed, this will not affect the implementation of these goals.
\end{abstract}

$\mathrm{T}$

HE REAGAN ADMINistration has assumed leadership of this country after decades of increasing federal involvement in all areas of American life. In higher education that involvement has been tied to increased federal assistance coupled with disproportionate growth in federal requirements. Government involvement in education has culminated in the creation of a separate department for education. During this period, however, the quality of education has not shown any marked improvement. Rather, the reverse has occurred as evidenced by the steady decline over many years of academic standards in test scores.

This administration believes that growth of federal involvement and intervention must be reversed. We believe that the federal government has gone beyond its authority in matters of education. The federal responsibility is to provide services fairly and to guarantee equal protection of the law to its citizens. In education, the federal role is to complement and supplement the efforts of parents, states, and local governments.

Under this administration we can expect a

Thomas Patrick Melady is assistant secretary for postsecondary education, United States government.

No copyright is claimed on this article, which the author wrote as part of his official duties as an employee of the U.S. government. reduction in the monitoring and enforcement role the federal government currently plays in education. Federal education programs will be simplified, and in some cases, consolidated. When federal intervention is required to address critical national needs or problems, state and local governments will be provided the autonomy and latitude to use available funds with increased responsibility and discretion.

As for the Department of Education, we are looking to fulfill President Reagan's promise to remove its cabinet status. In August of this year, Secretary Bell sent to the White House a paper that outlined options for the future configuration of the department. The options ranged from making it an independent agency or a foundation, to returning it to the Department of Health and Human Services (formerly Health, Education and Welfare), to scattering its functions among other federal agencies and departments. This has caused a great deal of discussion and concern about the possible demise or change in the philosophy of federal support to education. However, while the structure of the Department of Education is likely to change under the Reagan administration, the philosophy of federal support to education will remain essentially the same. In other words, regardless of the organizational placement of federal education programs, federal support to education will continue to 
be available through limited and appropriate financial assistance programs designed to address national needs.

The future of postsecondary education in the United States includes some uncertainty and probable change. It should be stressed at the outset that the federal government can not and will not be the answer to all of the challenges and changes that will face higher education in the 1980s. The federal role in education will continue to be restricted, as it has been in the past, by the Constitution. In addition, the focus of federal education efforts will be tied, more so than ever, to national economic problems and to issues of the security and strength of the nation.

The key to the future well-being of education, as well as the nation, is the extent to which inflation will be controlled. Educators and administrators are facing rising costs associated with labor costs, heating and cooling, maintenance, and operation of educational institutions. Hard decisions and possible trade-offs regarding academic programs are unfortunately being made in the face of these rising overhead expenses. Clearly, something must be done.

This administration has undertaken the awesome task of trying to control inflation and to restore this nation to economic health. The centerpiece of the strategy is fiscal responsibility in all aspects of federal spending, including education. It will no doubt be difficult for each of us to put aside individual interests and to begin thinking, acting, and reacting in terms of the larger collective interest of the well-being of the nation. However, we as educators must join in to help restore the economic health and security of the country and bring inflation under control. While the cuts will not be easy to endure in many cases, we must not lose sight of the fact that, in the long run, the economy will be revitalized, inflation lessened, and overhead in education reduced.

The underlying rationale for future budget strategies in postsecondary education is that the primary responsibility for a student's educational costs lies with the student and the family. Providing access to postsecondary education for low-income students will continue to be the highest priority for federal support to higher education. Consideration will also be given to choice and, to the extent possible, the federal government will continue to provide supplemental assistance to enable students to choose institutions most appropriate to their education and career aspirations. However, reforms in the student financial aid programs are based on the premise that the federal government should not bear the full burden of underwriting the total costs of education. To that end, students, their families, institutions, and the states will have to assume their proper share of financing education.

In addition to fiscal responsibility in federal spending, the higher-education community has every right to expect that the federal government will execute responsibly and with increased efficiency those programs under its authority that Congress has authorized. It is also reasonable to expect that we will work with you to explore creative and cost-effective ways to address and solve the challenges of the 1980s. In my view, there are several critical issues in postsecondary education that will require the very best thinking, cooperation, and mutual efforts of the federal government and the higher-education community. An outline of these issues follows.

The reduction of regulatory and paperwork burdens. This is one of the most vexing problems in higher education. Coping with the broad spectrum of government regulations is not merely time-consuming; it is counterproductive in that it requires valuable time and resources which could be devoted to the enhancement of academic programs. In addition, it is further complicated by the lack of adequate coordination among federal agencies. For example, of the more than four hundred federal education programs in the postsecondary sector, less than one-third are administered by the Department of Education. Institutions must comply with regulations from practically every department of the government. This administration has already made a number of initial reforms in this area. The Department of Education and other agencies, with the guidance, cooperation, and assistance of Vice-President Bush's Task Force on Regulations, are currently engaged in deregulation as well as procedures to reduce paperwork burdens.

The restoration of quality in education. There is no doubt in my mind that the quality 
of postsecondary education in this country has declined during the past two decades. It is evidenced by declining graduate and professional entrance examination scores, the failure of college graduates to communicate correctly and effectively, and the reexamination of curricula and the restoration of many core requirements discarded during the past decade.

In response to the growing concern about the decline of quality in education and in keeping with the responsibility to provide leadership and assistance to schools and colleges, the Department of Education has initiated a major campaign to encourage American schools, colleges, universities, and individuals in the education community to enhance excellence in learning. Secretary Bell has established a National Commission on Excellence in Education, which will be the centerpiece of this national effort to restore and promote quality in education. As the commission does its work over the next eighteen months, it will be conducting hearings across the country and collecting data to identify and study the problems in education. In addition, through the commission, we hope to identify successful programs and practices and to disseminate information about various educational models of excellence. Throughout the commission's work, special emphasis will be placed on writing with clarity and mastery of mathematics, spelling, basic science, economics, and the principles of government in a democracy.

Your support of and cooperation in this vital effort is encouraged and solicited. All of us must strive for educational excellence and to make quality education available to all people of this nation.

The continuation of access to higher education. We must ensure that all Americans will be treated fairly in attaining access to suitable forms of postsecondary education. As stated previously, this fundamental and worthwhile federal goal will continue to be supported by this administration.

The support of historically black colleges. Black colleges and universities have made a significant contribution to the diversity of American higher education. These institutions are national assets and continue to provide education and upward mobility for black Americans. Although they enroll about
20 percent of the approximately one million blacks in postsecondary education, they have produced about 50 percent of the black business executives and engineers, 75 percent of the black military officers, 80 percent of the black federal judges, and 85 percent of the black physicians in the United States.

The Reagan administration is committed to helping the historically black colleges and the students they serve. On September 15, 1981, President Reagan signed an executive order to strengthen the capacity of historically black colleges and universities to provide quality education. The executive order is designed to increase the participation of historically black colleges and universities in federally sponsored programs and to identify and eliminate barriers that may have resulted in reduced participation in federal programs. It is imperative that historically black colleges be maintained and strengthened. Through the executive order, this administration will assure that these vital national resources are preserved.

The expansion and improvement of foreign language and area studies. The needs of international commerce and the increasing interdependence of nations are but two reasons for the need to reexamine the role of American education within a worldwide community. It is unfortunate that most college graduates today do not have competence in any language other than English and that many of the nation's most prestigious colleges and universities do not require foreignlanguage competence for graduation. Students must be prepared not only to understand the world in which they live but also to participate in that world. With significant advances in travel and communications, peoples in the most distant countries are our nextdoor neighbors, and it is essential that we know how to effectively communicate with them and to understand their cultures.

In summary, we must take hold of our future and confront the changes facing us, seizing and molding them into our destiny. The future relationship between government and higher education must be one of partnership to address the issues and solve the problems that we must face. By working together, I believe, we can view the future with great excitement as a challenge and an opportunity. 